\title{
Erratum
}

\section{Detection of QTLs for traits associated with pre-harvest sprouting resistance in bread wheat (Triticum aestivum L.)}

\author{
Liangzi Cao, Kazuki Hayashi, Mayumi Tokui, Masahiko Mori, Hideho Miura and Kazumitsu Onishi* \\ Obihiro University of Agriculture and Veterinary Medicine, Obihiro, Hokkaido 080-8555, Japan
}

Breeding Science 66: 260-270 (2016)

In the above article, reference was incorrectly published. Therefore, we herewith would like to publish the correct reference.

True

Miura, H., N. Sato, K. Kato and Y. Amano (2002) Detection of chromosomes carrying genes for seed dormancy of wheat using the backcross reciprocal monosomic method. Plant Breed. 121: 394-399.

False

Miura, H., N. Sato, K. Kato, Y. Amano and R.A. Mcintosh (2002) Detection of chromosomes carrying genes for seed dormancy of wheat using the backcross reciprocal monosomic method. Plant Breed. 121: 394-399.

The online version of the original article can be found at https://www.jstage.jst.go.jp/article/jsbbs/66/2/66_260/_pdf

*Corresponding author (e-mail: onishi@obihiro.ac.jp) 